\title{
The Cloned Butyrylcholinesterase (BCHE) Gene Maps to a Single Chromosome Site, 3q26
}

\author{
P. W. Allderdice, ${ }^{*}$ H. A. R. Gardner, ${ }^{*}$ D. Galutira, ${ }^{*}$ O. Lockridge, $\dagger$ \\ B. N. LADU, $¥$ AND P. J. MCALPINE§ \\ "Faculty of Medicine, Memorial University of Newfoundland, St. John's, Newfoundland A1B 3V6, Canada; †Eppley Institute, \\ University of Nebraska Medical Center, Omaha, Nebraska 68198-6805; †Department of Pharmacology, University of Michigan \\ Medical School, Ann Arbor, Michigan 48109-0626; and §Department of Human Genetics, \\ University of Manitoba, Winnipeg, Manitoba R3E OW3, Canada \\ Received February 20, 1991; revised May 28, 1991
}

Human tissues have two distinct cholinesterase activities: acetylcholinesterase and butyrylcholinesterase. Acetylcholinesterase functions in the transmission of nerve impulses, whereas the physiological function of butyrylcholinesterase remains unknown. An atypical form of butyrylcholinesterase or the absence of its activity leads to prolonged apnea following administration of the muscle relaxant suxamethonium. Inheritance of these butyrylcholinesterase variants is consistent with the enzyme activity being encoded in a single autosomal locus, $B C H E$ (formerly $C H E 1$ and $E_{1}$ ), which has been assigned to chromosome 3. Previous in situ hybridization of a $B C H E$ cDNA probe gave evidence of homologous sequences at 3q26 and 16q11q23, raising the possibility of more than one locus coding for butyrylcholinesterase [H. Soreq, R. Zamir, D. ZevinSonkin, and H. Zakut (1987) Hum. Genet. 77: 325-328]. Using a different cDNA probe hybridized in situ to 46,XX,inv(3)(p25q21) metaphase chromosomes, we report here the localization of $B C H E$ to a single autosomal location: 3q26. @ 1991 Academic Press, Inc.

\section{INTRODUCTION}

Humans have two major types of cholinesterases: acetylcholinesterase (AChE, ${ }^{1} \mathrm{EC}$ 3.1.1.7) and butyrylcholinesterase (BChE, EC 3.1.1.8), which differ in their tissue distribution and catalytic properties (reviewed by Massoulié and Bon, 1982; Massoulié and Toutant, 1988; Chatonnet and Lockridge, 1989). $\mathrm{AChE}$, also referred to as "true cholinesterase," hydrolyzes acetylcholine at cholinergic synapses, whereas the true biological function of $\mathrm{BChE}$ remains obscure. BChE is known to hydrolyze the muscle relaxant suxamethonium, which is commonly administered during anesthesia. The production of prolonged apnea in about 1 in 2000 members of the general population following the administration of suxamethonium has been attributed to abnormal genetic variation of BChE (Kalow and Gunn, 1957). Sensitivity to

${ }^{1} \mathrm{AChE}$ and $\mathrm{BChE}$ refer to the enzyme; $B C H E$ refers to the gene. suxamethonium may be due to the atypical form of $\mathrm{BChE}$, which has reduced affinity for this substrate (reviewed by Whittaker, 1986) as the result of a point mutation in the BCHE structural gene (McGuire et $a l ., 1989$ ), or to the virtual absence of BChE activity. This latter phenotype, referred to as "silent," is attributed to a number of different mutations in the $B C H E$ gene (Nogueira et al., 1990). Additional variants of the $B C H E$ gene occurring as restriction fragment length polymorphisms have now been reported (Bartels et al., 1990; McAlpine et al., 1991).

The $B C H E$ locus, initially shown to be linked to the transferrin $(T F)$ locus (Robson et al., 1966), was subsequently mapped to chromosome 3 (Sparkes et al., 1984; Yang et al., 1984) and shown to be distal to 3q21 (McAlpine et al., 1987). When the first full-length cDNA clone of the $B C H E$ gene was used for in situ hybridization mapping studies, signals were reported initially at 3q21,3q26, and 16q11-q23 (Soreq et al., 1987a) and subsequently at 3q26 and 16q11-q23 (Soreq et al., 1987b). The occurrence of a site of hybridization on chromosome 16 prompted speculation that it could represent the locus encoding the C5 isozyme, detected by starch gel electrophoresis as an additional molecular species of $\mathrm{BChE}$ in $8 \%$ of the Caucasian population (Whittaker, 1986). A recent linkage study has shown that the CHE2 locus (formerly E2), to which the C5 isozyme is attributed, is linked to the $\gamma$-crystallin gene cluster (Eiberg et al., 1989), previously assigned to chromosome 2 (Willard et al., 1985; den Dunnen et al., 1985; Shiloh et al., 1986).

Five $B C H E$ genomic clones have been isolated (Arpagaus et al., 1990), using cDNA probes encoding the catalytic subunit of tetrameric enzyme (McTiernan $e t$ al., 1987). Analysis of these clones indicates that the $B C H E$ gene is at least $73 \mathrm{~kb}$ long and contains four exons (Arpagaus et al., 1990).

Our recent discovery of an RFLP of the $B C H E$ locus (McAlpine et al., 1991) using two of the five independently isolated genomic $B C H E$ clones (Arpagaus et al., 1990) prompted us to identify the chromo- 
somal origin of these clones for the facilitation of the interpretation of data from recombinational and physical versions of the map of chromosome 3 in our laboratories.

\section{MATERIALS AND METHODS}

\section{Probe}

The probe used contained an insert of $2.3 \mathrm{~kb}$ of $B C H E$ sequence, derived from a full-length cDNA, cloned by Dr. $O$. Lockridge.

\section{Lymphocyte Cultures}

Lymphocytes were isolated from a peripheral blood sample obtained from an inversion heterozygote, who is a member of a very large kindred in which an inv(3)(p25q21) segregates (Allderdice et al., 1975). Following culturing of the lymphocytes as described by Buckle and Craig (1986) for $72 \mathrm{~h}, 20 \mu \mathrm{g} / \mathrm{ml}$ bromodeoxyuridine (BRdU) was added and 16-17 h later the block was released by the addition of medium containing $10^{-5} M$ thymidine. Cells were harvested $4-5 \mathrm{~h}$ later after a $20-\mathrm{min}$ exposure to $0.05 \mu \mathrm{g} / \mathrm{ml}$ colcemid and $13 \mathrm{~min}$ in $0.075 \mathrm{M}$ potassium chloride. The cell suspension was dropped and air-dried on slides.

In situ hybridization was carried out as described by Craig et al. (1988). Slides were treated with RNase $(100 \mu \mathrm{g} / \mathrm{ml}$ in $2 \times \mathrm{SSC})$ at $37^{\circ} \mathrm{C}$ for $1 \mathrm{~h}$, rinsed in $2 \times$ SSC, dehydrated through alcohol series, and airdried. The slides were denatured at $65^{\circ} \mathrm{C}$ for $4 \mathrm{~min}$ in $70 \%$ formamide and $0.1 \mathrm{~m} M$ EDTA in $2 \times \mathrm{SSC}$, rinsed twice in $2 \times \mathrm{SSC}$ (the first chilled to $4^{\circ} \mathrm{C}$ ), and then dehydrated. The $B C H E$ probe $(50 \mathrm{ng})$ was radiolabeled to a specific activity of $6.1 \times 10^{7} \mathrm{dpm} / \mu \mathrm{g}$ with $\left[{ }^{3} \mathrm{H}\right] \mathrm{dCTP}$ by random primer extension using the multiprime DNA labeling system (Amersham) according to the manufacturer's specifications. The labeled probe was added at a concentration of $125 \mathrm{ng} /$ $\mathrm{ml}$ to $350 \mu$ l hybridization mix (Sigma) and denatured by boiling for $5 \mathrm{~min}$. Then $30 \mu \mathrm{l}$ of the labeled probe was placed on each slide, the coverslip was sealed with rubber cement, and the slides were incubated at $43^{\circ} \mathrm{C}$ for $20 \mathrm{~h}$. The slides were rinsed in $5 \times \mathrm{SSC}$, washed in $2 \times \mathrm{SSC}$ three times for $20 \mathrm{~min}$ each, and split into two batches, one being washed in $0.2 \times \mathrm{SSC}$ at $60^{\circ} \mathrm{C}$ and the other in $2 \times \mathrm{SSC}$ at $65^{\circ} \mathrm{C}$. Both washes were for $1 \mathrm{~h}$ (with one change) after which all slides were washed two times in $0.2 \times$ SSC for $30 \mathrm{~min}$ and two times in $0.1 \times$ SSC for $30 \mathrm{~min}$ and dehydrated.

Slides were then dipped in Kodak NTB2 emulsion and exposed $13-18$ days at $4^{\circ} \mathrm{C}$. Following development in Kodak D19 for $7 \mathrm{~min}$ at $20^{\circ} \mathrm{C}$, slides were fixed, washed, then stained with Hoechst 33258 (10 $\mu \mathrm{g} / \mathrm{ml}$ in $2 \times \mathrm{SSC}$ ) for $30 \mathrm{~min}$, exposed in $2 \times \mathrm{SSC}$ to uv light for $1 \mathrm{~h}$, and stained with $10 \%$ Giemsa for $30 \mathrm{~min}$. Grains on, or touching, the chromatids were scored

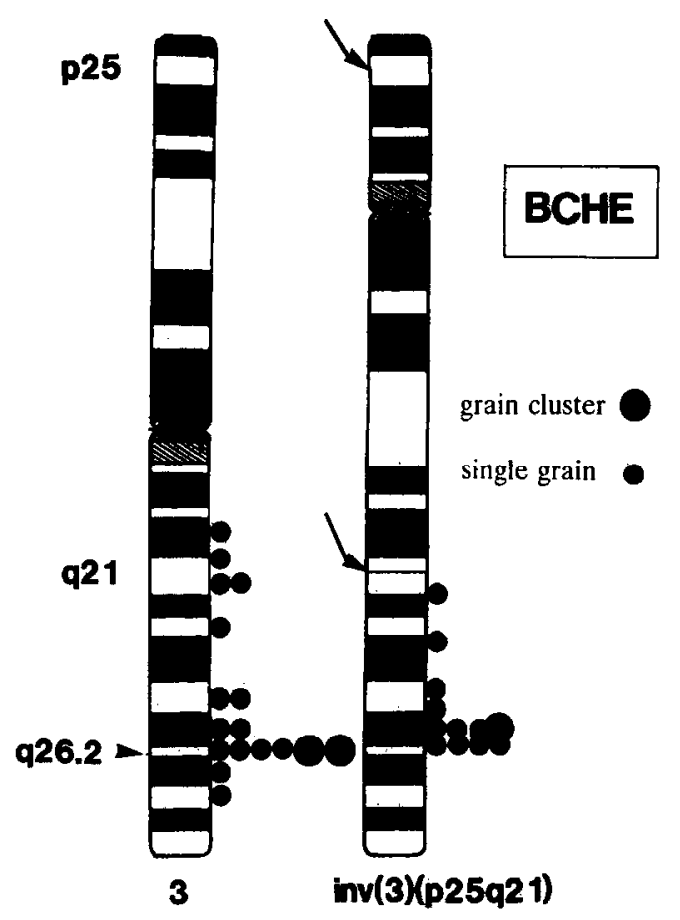

FIG. 1. Idiogram of human chromosomes from an inv(3)(p25q21) heterozygote showing the distribution of silver grains after autoradiography of ${ }^{3} \mathrm{H}$-labeled $B C H E$ cDNA probe.

according to chromosomal location, with clusters of grains counted as one grain.

\section{RESULTS}

A clear signal was present on both the normal chromosome 3 and the inv(3) chromosome at 3q26 (Fig. 1) on the slides washed at the higher stringency $(2 \times$ SSC). Silver grains on the other autosomes, including chromosome 16, appeared to be distributed randomly, without evidence of clustering. Of the total 131 grains scored from 53 complete 46 ,XX,inv(3) metaphases, $10.9 \%$ mapped distal to the $3 \mathrm{q} 21$ breakpoint. When only chromosome 3 and the inv(3) were examined, an additional 10 grains were located in 6 cells. Combined counts from partial and complete cells showed 28 of 32 grains on chromosome 3 and/or the inv(3) distal to the q21 breakpoint. Fifty percent of the grains distal to this breakpoint, including 3 clusters, mapped to 3q26. The signals on the normal and inv(3) chromosome were in comparable locations and not influenced by the inv(3)(p25q21), indicating that the $B C H E$ locus is clearly distal to $3 \mathrm{q} 21$, which contains the $T F$ locus to which it is linked.

\section{DISCUSSION}

The clustering of signal at 3q26 on both the normal and the inv(3) chromosomes indicates a single geno- 
mic site for $B C H E$ coding sequences. A single copy of the $B C H E$ locus, as indicated by the data presented here, is consistent with the data obtained from the nucleotide sequence and polymerase chain reaction studies reported earlier by Arpagaus et al. (1990) and La Du et al. (1991). The absence of signal on 2q, where CHE2 has been assigned, suggests that the locus to which the C5+ phenotype is attributed does not code for a butyrylcholinesterase. Furthermore, no evidence of a signal with the $B C H E$ cDNA probe to any location on chromosome 16 was obtained. Thus, the previous report of Soreq et al. (1987b) of a $B C H E$-like sequence on chromosome 16 detected by in situ hybridization with a different cDNA probe cannot be confirmed. The finding of a single genomic location for the gene encoding butyrylcholinesterase gives confidence for using RFLP analysis of this locus for linkage studies of chromosome 3 markers.

\section{ACKNOWLEDGMENTS}

Financial support for this project was provided by the Medical Research Council of Canada (MT6112, P.J.M.; MT6725, P.W.A.), the Children's Hospital of Winnipeg Research Foundation, Inc. (P.J.M.), and NIH Grant GM27028 (B.N.L.). M. Huebner provided expert secretarial assistance.

Note added in proof. Since this manuscript was submitted, G. Gaughan et al. (1991, Genomics 11: 455-458) have confirmed the regional localization of $B C H E$ to $3 \mathrm{q} 26$ using a PCR-derived probe.

\section{REFERENCES}

1. Allderdice, P. W., Browne, N., AND MurPhy, D. P. (1975). Chromosome 3 duplication q21-qter deletion p25-pter syndrome in children of carriers of a pericentric inversion inv(3) (p25q21). Am. J. Hum. Genet. 27: 699-718.

2. Arpagaus, M., KotT, M., Vatsis, K. P., Bartels, C. F., La Du, B. N., AND LOCKRIDGE, O. (1990). Structure of the gene for human butyrylcholinesterase: Evidence for a single copy. Biochemistry 29: 124-131.

3. Bartels, C. F., van Der Spek, A. F. L., AND LA Du, B. N. (1990). Two polymorphisms in the non-coding region of the BCHE gene. Nucleic Acids Res. 18: 6171.

4. BUCKLE, V. J., AND CRAIG, I. W. (1986). In situ hybridization. In "Human Genetic Diseases, A Practical Approach" (K. Davies, Ed.), Vol. 6, pp. 85-100, IRL Press, Washington, DC.

5. Chatonnet, A., AND Lockridge, O. (1989). Comparison of butyrylcholinesterase and acetylcholinesterase. Biochem. $J$. 260: 625-634.

6. Craig, S., Buckle, V. J., Mallet, J., and Craig, I. W. (1988). Localization of the human dopamine beta hydroxylase $(D B H)$ gene to chromosome 9q34. Cytogenet. Cell Genet. 48: 48-50.

7. Den Dunnen, J. T., Jongbloed, R. J. E., Lubsen, N. H., Geurts van Kessel, A. H. M., Westrgreld, A., AND Schoenmakers, J. G. G. (1985). Human lens gamma-crystallin sequences are located in the p12-qter region of chromosome 2. Cytogenet. Cell Genet. 40: 616.

8. Eiberg, H., Nieldeen, L. S., Klausen, J., Dahlen, M., KrisTEnsen, M., BisgaArd, M. L., Moller, N., AND Mohr, J. (1989). Linkage between serum cholinesterase 2 (CHE2) and $\gamma$-crystallin gene cluster (CRYG): Assignment to chromosome 2. Clin. Genet. 35: 313-321.
9. KaLOW, W., AND GUNN, D. R. (1957). The relation between dose of succinylcholine and duration of apnea in man. $J$. Pharmacol. Exp. Ther. 120: 203-214.

10. La Du, B. N., Bartels, C. F., Nogueira, C. P., Arpagaus, M., AND LockridGe, O. (1991). Proposed nomenclature for human butyrylcholinesterase genetic variants identified by DNA sequencing. Cell. Mol. Neurobiol. 11: 79-88.

11. Massoulí, J., AND Bon, S. (1982). The molecular forms of cholinesterase and acetylcholinesterase in vertebrates. Annu. Rev. Neurosci. 5: 57-106.

12. Massoulí, J., AND TOUTANT, J.-P. (1988). Vertebrate cholinesterases: Structure and types of interaction. Handb. Exp. Pharmacol. 86: 167-224.

13. McAlpine, P. J., Allderdice, P. W., Cox, D. W., Simpson, N. E., McEachraì, M., and Komarnicki, L. (1987). The ordering of TF:CHE1:AHSG and their orientation distal to 3q21. Cytogenet. Cell Genet. 46: 659.

14. Mcalpine, P. J., Dixon, M., Allderdice, P. W., LOCKRIDGE, O., AND LADU, B. N. (1991). The butyrylcholinesterase 1 gene (BCHE1) at 3q26 shows two RFLP's. Nucleic Acids Res., in press.

15. McGuire, M. C., Noguetra, C. P., Bartgls, C. F., LightSTONE, H., HaJRA, A., VAN Der SPEK, A. F. L., Lockridge, O., AND LA DU, B. N. (1989). Identification of the structural mutation responsible for the dibucaine-resistant (atypical) variant form of human serum cholinesterase. Proc. Natl. Acad. Sci. USA 86: 953-957.

16. Mctiernan, C., Adkins, S., Chatonnet, A., Vaughan, T. A., BARTELS, C. F., KoTT, M., ROSENBERRY, T. L., LADU, B. N., AND LOCKRIDGE, O. (1987). Brain cDNA clone for human cholinesterase. Proc. Natl. Acad. Sci. USA 84: 66826686.

17. Nogueira, C. P., McGuire, M. C., Graeser, C., Bartels, C. F., ARpagaus, M., VAN DER SPEK, A. F. L., Lightstone, H., LockriDge, O., AND LA DU, B. N. (1990). Am. J. Hum. Genet. 46: 934-942.

18. Robson, E. R., SuthHerLaNd, I., AND HARRIS, H. (1966). Evidence for linkage between the transferrin locus (Tf) and the serum cholinesterase locus (E1) in man. Ann. Hum. Genet. 29: 325-336.

19. Shiloh, Y., Donlon, T., BRUNS, G., Breitman, M. L., AND Tsui, L.-C. (1986). Assignment of the human gamma-crystallin gene cluster (CRYG) to the long arm of chromosome 2, region q33-q36. Hum. Genet. 73: 17-19.

20. SoReQ, H., ZAMIR, R., AND ZAKUT, H. (1987a). Human cholinesterase genes localized by hybridization to chromosomes 3 and 16. Cytogenet. Cell Genet. 46: 695.

21. SoreQ, H., Zamir, R., Zevin-Sonkin, D., AND ZaKuT, H. (1987b). Human cholinesterase genes localized by hybridization to chromosomes 3 and 16. Hum. Genet. 77: 325-328.

22. Sparkes, R. S., Field, L. L., Sparkes, M. C., Crist, M., SPENCE, M. A., JAMES, K., AND GARRY, P. J. (1984). Genetic linkage studies of transferrin, pseudocholinesterase, and chromosome 1 loci. Hum. Hered. 34: 96-100.

23. WhitTaker, M. (1986). In "Monographs in Human Genetics" (L. Beckman, Ed.), pp. 7-15 and 45-63, Karger, Basel.

24. Willard, H. F., Meakin, S. O., Tsui, L.-C., and Brettman, M. L. (1985). Assignment of human gamma crystallin multigene family to chromosome 2. Somatic Cell Mol. Genet. 11: 511-516.

25. YANG, F., LUM, J. B., MCGILl, J. R., MOORE, C. M., NAYloR, S. L., van Bragt, P. H., Baldwin, W. D., and Bowman, B. H. (1984). Human transferrin: cDNA characterization and chromosomal localization. Proc. Natl. Acad. Sci. USA 81: 2752-2756. 